\title{
Digital Inclusion and the Elderly: The Case of Internet Banking Use and Non-Use among older Adults in Ekiti State, Nigeria
}

\author{
Funmilola O. Omotayo ${ }^{1} \&$ Tolulope A. Akinyode ${ }^{2}$ \\ Africa Regional Centre for Information Science, \\ University of Ibadan, Nigeria. \\ ${ }^{1}$ lolaogunesan@yahoo.com, ${ }^{2}$ tolex86@gmail.com
}

Received: 28.03.2020 Accepted: 23.05.2020

Date of Publication: June, 2020

\begin{abstract}
The level of acceptance and use of Internet banking (IB) among older adults is a major issue toward the advancement of banking operations in Nigeria. So far, there has been little or no representation of older adults $(60+)$ in studies conducted on IB adoption and use in Nigeria. Hence, this study investigated the use of IB among older adults in Ekiti State Nigeria. The selection of the sample was made through purposive, convenience, and snowball sampling techniques. Nine local government areas were purposively selected to have a mix of urban and rural areas. Convenience and snowball sampling techniques were used to select 384 older adults, while questionnaires and interviews were used to collect data. Findings reveal that most of the elderly have not adopted the use of IB as they preferred and used the traditional banking system. Those that have adopted IB for their banking transactions averagely used it majorly for funds transfer, bills payment, and airtime top-up. Convenience was the major reason for using IB by the users, while the non-users mentioned unawareness and security concerns as reasons for not using. The users have the intention of continuing using the technology, while the non-users have the intention of using it in the future. It is recommended that banks should intensify efforts at creating awareness of IB as well as its benefits to this group of customers to ensure they are digitally included in the transformations going on in the financial sector.
\end{abstract}

Keywords: Use of Internet Banking, Awareness, Convenience, Digital Inclusion, Older Adults, Ekiti State, Nigeria. 


\section{Introduction}

Over the past decades, technology has permeated every aspect of modern society, while use of various technologies is becoming an integrated part of people's everyday lives. This has resulted in constant technological development, which has made many services and resources available and accessible only through digital means. Along with this trend, virtually every nation of the world is experiencing growth in the number and proportion of the elderly population (United Nations, 2015), which is introducing many new challenges to the society. Some of these challenges have to do with ensuring digital inclusion for every individual. Even though some older adults could use digital technologies, many find themselves without sufficient skills to use these technologies, making them digitally divided. A vast majority of the aged population have less familiarity with digital technologies as they did not have the opportunity to learn and use them during their younger years, having been born when these technologies were not yet commonplace (Morris \& Venkatesh, 2000; Smith, 2014). This makes them experience difficulties using facilities, services, and opportunities made available through digital technologies (Lawhon, Ennis, \& Lawhon, 1996). Without appropriate skills and interventions, this group of people risks being excluded from participating fully in the present modern society.

WHO (2002) described the elderly people as precious and often ignored population that makes an important contribution to the fabric of the societies. They are a heterogeneous group with different needs and capabilities learning abilities, behaviors, and functional capacity.
Aging is associated with a reduction in visual acuity, contrast discrimination, and the precision of eye-movement control. Other constraints related to old age are cognitive impairment, short memory, dementia, weakness, motor control difficulties, and declining ability to learn and retain information on new subjects. It has, however, been noted that digital technologies such as mobile phones, computers, digital home electronic appliances, Internet banking, and many other assistive technologies offer a wide range of solutions for older adults to stay healthy, and live independently, and help counteract the reduced capabilities which are more prevalent with old age (Goyal and Dixit, 2008; Näsi, Räsänen, \& Sarpila, 2012; Sayago, Forbes, \& Blat, 2012). Hence, as a result of increasing reliance on digital technologies to conduct activities associated with daily living, research to understand the level of adoption and use of these technologies by the elderly is seen as crucial to promote their adoption among the elderly, help them tap from the benefits associated with their use, remain relevant, active, independent and vitally included and engaged in the society, even at old age.

Increasing the development of digital technologies, particularly in the use of the Internet for business transactions, has transformed banking operations from traditional system to an electronic banking (e-banking) system (Aliyu \& Tasmin, 2012). E-banking is the use of an automated information system to carry out financial transactions with or without bank customers' physical presence at bank premises or designated locations. E-banking makes financial technologies (banking channels) accessible at customers' convenience without the need to be 
physically present at the bank premises. Today, nearly all banking activities, ranging from funds transfer, online payments for goods and services, bank statement inquiry, payment of bills, telephone voucher top-up, and many more can be carried out by bank customers through e-banking. Ebanking is one of the financial technologies that can assist the financial well-being of the adults as well. There are many types of ebanking: mobile banking, Internet banking (IB), automated teller machine, telebanking, smart card, debit card, credit card, etc. Internet banking is a type of e-banking that is popular due to the convenience of having an online banking account. It is a robust channel designed with the state-of-the-art technology that gives bank customers unlimited access to their accounts remotely and allows them to conveniently perform many bank transactions online real-time.

Many nations of the world are going cashless through exploiting the many benefits of the Internet to improve their economy. It has, however, been observed that despite many advantages of IB, a cross-section of consumers still does not use the technology (Braganza \& Mekoth, 2017; Lee, Kwon, \& Schumann, 2005). It is also noted that IB has only been designed with financial inclusion of the mass market in mind, and not for those heavily reliant on cash, for instance, the elderly, and those who live in rural communities where there is no Internet access. For the older generation, who often depend on cash, this new-found dominance of digital banking is an upward struggle. Taking into cognisance the fact that cash is a key part of national infrastructure, and not just a commercial issue, it means a number of bodies have to ensure there is financial inclusion for everyone, including the older people and rural dwellers who may be disadvantaged to use e-banking as a result of their age, background or location. Studies have also shown that, with the immense services made available through different e-banking channels by banks, the older population appears to prefer the execution of financial transactions over the counter in the banking hall to e-banking channels (DutchNews).

Nigeria is experiencing what feels like an inevitable movement towards a cashless society as all banks in Nigeria have exploited the potential of digital technology in expediting service delivery through electronic channels, such as IB, which offers cost-saving potential to both service providers and users. Although few Nigerian older people use the Automated Teller Machine (ATM) and mobile banking through Unstructured Supplementary Service Data, it has been observed that a high percentage have not keyed into using IB. Many reasons could be attributed to this, which makes it imperative to carry out a study on the level of adoption and use of IB among Nigerian older adults, and to find out the factors that influence or inhibit the use of IB among this population. Studies (e.g. Yousafzai \& Yani-de-Soriano, 2012) have explained that the ability to adopt new technology depends on many factors. Older adults are less familiar with the technology, 
hence their use or non-use of IB would depend on some factors. Also, extensive research has been carried out on the use of IB by bank customers, whereas not much research has considered the non-use of IB. Since IB is a popular and fast-growing delivery channel by banks, a comprehensive study on the use and non-use of IB services would be of great significance to both the academicians and the banking industry alike. This would also provide empirical data to compare the use and non-use of IB among the older population. Thus, this study sought to have a better understanding of issues and concerns of the older population toward the use and non-use of IB. The study investigated the mode of banking preferred by older adults, the frequency of IB usage among them, the feature(s) of IB mostly used by those that have adopted IB, the reasons for use by the users, reasons for non-use by the nonusers, and whether the non-IB users have the intention of using the technology in the future.

\section{Literature Review}

In a bid to catch up with the global trend in ICT developments in banking, the Central Bank of Nigeria (CBN) introduced the cashless policy in 2012 to curb excesses in the handling of cash in Nigeria. The policy was enforced, not to eliminate the use of cash but, to reduce the volume of cash in circulation and encouraging more electronic-based transactions (payments for goods, services, transfers, etc.) In the same vein, virtually all commercial banks in Nigeria have adopted e-banking to reach out to customers across the world and improve on their service delivery, decongest queues in the banking hall, as well as a key into the CBN policy. Hence, there has been the massive deployment of ATMs, point of sale terminal (POS), development of webbased banking, as well as telephone banking platforms for the use of bank customers in Nigeria.

However, while the use of electronic banking, especially IB has been prevalent among the young generations, observations reveal that technology seems not to be widely used by older adults. Review of literature on technology adoption by older adults reveals numerous studies that have been done to investigate the use of various technologies by older adults. Most of these studies (e.g. Barnard, Bradley, Hodgson, \& Lloyd, 2013; Berkowsky, Sharit, \& Czaja, 2018; Delello \& McWhorter, 2017; Gitlow, 2014; Hill, Betts, \& Gardner, 2015; Li \& Luximon, 2018; Marston, Kroll, Fink, de Rosario, \& Gschwind, 2016; Omotayo, 2015; Peek et al., 2015; Pew Research Centre, 2014; Ronning \& Solvberg, 2017) focused on general technology use, with few focusing on IB usage among the older population. However, few studies (e.g. Camilleri \& Grech, 2017; Piiparinen, 2014) have been able to confirm low adoption and use of IB among older adults, even in developed countries where there are availability and easy access to facilities needed to use the technology. For instance, Piiparinen (2014) investigated the attitudes of seniors, aged 65+, using cash services towards online banking in the Turku region, Finland. The research focused on identifying the reasons why cash service customers were not using 
online banks, and the prospects in their use of online banks. A short structured interview revealed that $70 \%$ of the senior customers using the bank's cash services were not using online banks and only $12 \%$ of them were interested in starting to use. The findings also showed that the seniors relied on faceto-face services of banks and actively used banks' cash services rather than the online services. The seniors were not willing to use online banks, because they did not have access or knowledge to use the equipment, their physical condition. The study of Camilleri and Grech (2017) focused on the relevance of age categories in explaining IB adoption rates and customers' attitudes towards the service. The study explored the adoption rate of bank customers toward IB in Malta with a relative importance of age categories. The results revealed that, younger adults (aged 18-34) had a high preference for IB, while preference for IB among older adults (aged 50-68) was low, which implies, younger adults used IB more than the older ones. More so, it was noted that, lack of information about IB service, faceless banking, computer illiteracy, and unavailability of the Internet were the major reasons for the low rate of IB adoption among the older adults. Besides, it was opined that, the non-adopter (mostly the older adults) could be encouraged to accept and use IB if the design interface navigations are made simpler, demonstration guides are made available, and motivations from family and friends.

Some other research works (e.g. Ainin, Lim, \& Wee, 2005; Asmi \& Ishaya,
2012; Ding, Verma \& Iqbal, 2007; Howcroft, Hamilton, \& Hewer, 2002; Karjaluoto, Mattila, \& Pento, 2002; Laukkanen, Sinkkonen, Kivijarvi \& Laukkanen, 2007; Mattila, Karjaluoto, \& Pento, 2003; Rock, Hira, \& Loibl, 2010) have found that there is a significant effect of aging on the use of IB. For instance, Ainin, Lim and Wee (2005) found a negative and significant relationship between age and IB adoption, probably because the elderly were more resistant to change and had a negative attitude toward using IB services. Laukkanen, Sinkkonen, Kivijarvi, and Laukkanen (2007) and Asmi and Ishaya (2012) also found that the elderly people, in their studies, preferred to have face-to-face communication with regards to banking, where possible. Likewise, Rock, Hira, and Loibl (2010) showed that older respondents in the USA were less likely to use the Internet as a source of financial information, even though the reasons for this were not security concerns, but that they preferred contact with bank workers due to websites being difficult or confusing. Hill, Beynon-Davies and Williams (2008) study also revealed that, for people over 50 years old, the perception of the relative advantage of IB was weaker than the perception of other technologies, probably due to perceptions of risk and security.

However, aging is not the only explanation of the rejection of IB among older adults; some other factors have also been found to influence IB adoption among this population. The study of Lichtenstein and Williamson (2006) showed that elderly Australians 
with low incomes did not use IB because of lack of awareness toward IB and its advantages, lack of internet access and internet confidence, inadequate knowledge, and support for use or the initial setting up procedure, lack of trust, security and high perceived privacy risks. Sohail and Shanmugham (2004) also found that age had no significant impact on ebanking adoption. Instead, they argued that accessibility to the Internet, awareness of e-banking and customers' resistance to change are the main factors influencing e-banking adoption. Also, Nayak, Priest and White (2010) showed that, for older adults aged 6088 , and for more complex internet activities, such as banking transactions, gender (male), health status (good), perceived usefulness, and attitude were the significant factors. Also, Senali (2017) investigated mobile banking adoption by senior citizens, aged 55+, in Australia and found that the ownership of smartphones was high, however, the adoption of smartphones and mobile banking by the elderly was low. Some of the reasons for the nonadoption of mobile banking are fear of hackers, lack of knowledge, psychological decline, and limitations of technology. The study concluded that adoption and use of mobile banking can improve the quality of life and well-being of aging Australians, and MB adoption can be improved if banks can address the obstacles pointed out, thereby alleviating the concerns of the adults. Asmi and Ishaya (2012) investigated the behaviour of elderly people (age segment 55-65) towards IB in the UK. The research provides an understanding of the level of motivations, social influence, perceived usefulness, and ease of use of IB for the age segment in the UK. More than $45 \%$ of non-users of IB in the study had most of the facilitating conditions and had enough self-efficacy to perform IB related tasks, yet were not using IB. The respondents preferred the traditional banking system where they have face-to-face interaction, while social norms in the form of 'peer influence' shows less influencing variable as compared to the impact of 'attitude' in defining behaviour towards IB by the elderly people. The study concludes that financial institutions should motivate and encourage the elderly to use IB services.

This literature has been able to reveal that adoption and use of IB among the elderly across the world is still very low, most especially in developing countries. Most of the literature reviewed has also highlighted many reasons for the low adoption of this technology among the elderly, which then calls for the need to find out the level of adoption in Nigeria as well as the reasons for use or non-use among Nigeria's older adults.

\section{Methodology}

A survey research design was adopted for the study. The population of the study is older adults above 60 years, who are account holders of commercial banks in Ekiti State in Southwestern Nigeria. The population of older adults in Ekiti state who are bank customers is indeterminate; hence, purposive, convenience, and snowball sampling techniques were then used to select the 
sample. At the first stage, nine local government areas (LGAs) (Ado-Ekiti, Ijero, Ekiti West, Ikole, Ekiti Southwest, Ekiti East, Gboyin, Oye and Ikere) were purposively selected out of the sixteen LGAs in Ekiti State to have a mix of urban and rural areas. The LGAs were also purposively chosen as a result of the availability of commercial banks, as well as the availability of Internet access in the areas. In the second stage, two towns or villages were chosen from each LGA, where the towns or villages were drawn based on settlement types, that is, urban, semi-urban and rural, as specified on the official website of the state

(http://ekitistate.gov.ng/about\%20ekiti/)

At the third stage, 384 older adults were selected through convenience and snowball sampling techniques; 192 IB users and 192 non-IB users.

Two sets of questionnaire were used for data collection. The questionnaires consist of both open and close-ended questions. Measurement items were adopted from previous studies of Ashour and Badah (2010), Braganza and Mekoth (2017), Mbrokoh (2015), Mwesigwa (2010), and Onyango (2016) on in e-banking adoption and use. The questionnaires elicited information about the demographics of the older adults, possession of mobile phones and computers, accessibility to the Internet connection, preferred banking modes, frequency and length of use of IB, feature(s) of IB are mostly used by the older adults, reasons for using $\mathrm{IB}$, reasons for not using $\mathrm{IB}$, and intention/readiness to use IB by non-IB users. The interview was used to complement the questionnaire. The interview schedules were constructed to accommodate more oral open-ended responses. The validity of the instruments was examined by two researchers in the fields of information science and banking for face and content validity. The reliability of the instrument was tested through internal consistency. The instruments were pretested in Agbowo and Bodija areas in Ibadan, Oyo State, which are not part of the study locations.

Administration of the two sets of the questionnaire and the interview sessions were conducted by the researchers with the help of three research assistants who were briefed about the research topic, objectives, and contents of the instruments. In the end, only 47 IB users participated in the study as the others did not return the questionnaire even after many repeated visits to them, thereby giving a $24.5 \%$ response rate. The reason for this low response could be because some of the older adults who said they were IB users may not be after all, as many of them kept saying they had not filled the questionnaire, while some said they had lost it. Even after the lost ones were replaced, they still kept saying they had not filled them. Some said they were waiting for their children to show them the instrument before filling. The researchers stopped visiting them when it was obvious that some of them were just not willing to participate and some may not even be using IB as professed by them initially. However, all the copies of the questionnaire administered to the 192 respondents selected for the non-IB users were 
retrieved, properly filled, and useful for data analysis; giving a $100 \%$ response rate. The overall valid sample for this study is 239 (62.2\% response rate).

In addition, interview appointments were scheduled with 20 respondents (10 IB users and 10 non-IB users) among the ones served with questionnaires in some of the research locations. The locations visited for interviews are Ado, Ijero, Ikole, Oye, and Ikere. An audio recording device was used to capture responses with the permission of the respondents. Respondents were made to be aware of the purpose of conducting this study to get their informed consent, and made them understand that the study is purely for research purposes. More so, the researchers assured the respondents of the anonymity and confidentiality of their responses. Only respondents that were willing to participate in the study were involved to avoid coercion.

Some challenges were encountered during the data collection as many of the older adults approached declined to participate in the study because they had no idea of IB, some could not read and write, while some showed lack of interest. It was also observed that most of the adults approached were not using $\mathrm{IB}$; hence, the reason for the low number of IB users (47) compared to the projected sample (192). Statistical
Package for Social Science version 20 (SPSS 20) was used to analyse data using descriptive statistics. Qualitative data were analysed thematically with Nvivo software (version 10). The transcribed audio responses of respondents were grouped and categorised into themes (nodes) in regards to the objectives and research questions and thematic analysis was conducted. The analysis and results were presented based on the themes concerning the research objectives and questions.

\section{Findings and Discussion}

\subsection{Frequency Distribution of Respondents Demographics}

Table 1 presents the frequency and percentages of the respondents' demographics for IB and non-IB users. The majority of the respondents are non-IB users (19.7\% IB users; $80.3 \%$ non-IB users). Most (76.6\%) of the IB users and non-IB users (62.0\%) were within the age range of 60-69 years. More males than females participated in the study $(80.9 \%$ IB users; $60.0 \%$ non-IB users). In the category of the IB user, most had Nigeria Certification in Education (42.6\%), while $35.9 \%$ of the non-IB users had Nigeria Certification in Education. Some of the LGAs do not have respondents who are IB users, while all the LGAs had representatives for non-IB users. 


\begin{tabular}{|c|c|c|c|c|c|}
\hline \multirow{2}{*}{\multicolumn{2}{|c|}{ Demographic Variables }} & \multicolumn{2}{|c|}{ IB Users } & \multicolumn{2}{|c|}{ Non-IB Users } \\
\hline & & $\begin{array}{c}\text { Freq } \\
(\mathrm{N}=\mathbf{4 7})\end{array}$ & $\%$ & $\begin{array}{c}\text { Freq } \\
(\mathrm{N}=\mathbf{1 9 2}) \\
\end{array}$ & $\%$ \\
\hline \multicolumn{6}{|l|}{ Age } \\
\hline \multicolumn{2}{|c|}{$60-69$ years } & 36 & $\begin{array}{l}76 . \\
6 \\
\end{array}$ & 119 & $\begin{array}{l}62 . \\
0\end{array}$ \\
\hline \multicolumn{2}{|c|}{$70-79$ years } & 11 & $\begin{array}{l}23 . \\
4\end{array}$ & 64 & $\begin{array}{l}33 . \\
3\end{array}$ \\
\hline \multicolumn{2}{|c|}{80 years and above } & 0 & 0.0 & 9 & 4.7 \\
\hline \multicolumn{6}{|l|}{ Sex } \\
\hline \multicolumn{2}{|l|}{ Male } & 38 & $\begin{array}{l}80 . \\
9\end{array}$ & 115 & $\begin{array}{l}59 . \\
9\end{array}$ \\
\hline \multicolumn{2}{|l|}{ Female } & 9 & $\begin{array}{l}19 . \\
1\end{array}$ & 77 & $\begin{array}{l}40 . \\
1\end{array}$ \\
\hline \multicolumn{6}{|c|}{ Level of Education } \\
\hline \multicolumn{2}{|c|}{ PhD Degree } & 0 & 0.0 & 0 & 0.0 \\
\hline \multicolumn{2}{|c|}{ Master's Degree } & 3 & 6.4 & 11 & 5.7 \\
\hline \multicolumn{2}{|c|}{ Bachelor's Degree } & 4 & 8.5 & 32 & $\begin{array}{l}16 . \\
7\end{array}$ \\
\hline \multicolumn{2}{|c|}{ Higher National Degree } & 11 & $\begin{array}{l}23 . \\
4\end{array}$ & 46 & $\begin{array}{l}24 . \\
0\end{array}$ \\
\hline \multicolumn{2}{|c|}{ Ordinary National Degree } & 9 & $\begin{array}{l}19 . \\
1\end{array}$ & 14 & 7.3 \\
\hline \multicolumn{2}{|c|}{$\begin{array}{l}\text { Nigeria Certification in } \\
\text { Education }\end{array}$} & 20 & $\begin{array}{l}42 . \\
6\end{array}$ & 69 & $\begin{array}{l}35 . \\
9\end{array}$ \\
\hline \multicolumn{2}{|c|}{ Grade II } & 0 & 0.0 & 3 & 1.6 \\
\hline \multicolumn{2}{|c|}{ SSCE/WASSCE } & 0 & 0.0 & 4 & 2.0 \\
\hline \multicolumn{2}{|c|}{$\begin{array}{l}\text { Primary School Leaving } \\
\text { Certificate }\end{array}$} & 0 & 0.0 & 13 & 6.8 \\
\hline \multicolumn{2}{|c|}{ No Formal Education } & 0 & 0.0 & 0 & 0.0 \\
\hline \multicolumn{6}{|l|}{ Location } \\
\hline \multirow{2}{*}{$\begin{array}{l}\text { Ado-Ekiti } \\
\text { LGA }\end{array}$} & Ado-Ekiti & 11 & $\begin{array}{l}23 . \\
4\end{array}$ & 13 & 6.8 \\
\hline & Ilokun-Ekiti & 0 & 0.0 & 10 & 5.2 \\
\hline \multirow[b]{2}{*}{ Ijero LGA } & Ijurin-Ekiti & 1 & 2.1 & 10 & 5.2 \\
\hline & Ijero-Ekiti & 5 & $\begin{array}{l}10 . \\
6\end{array}$ & 13 & 6.8 \\
\hline \multirow{2}{*}{$\begin{array}{l}\text { Ekiti West } \\
\text { LGA }\end{array}$} & Aramoko-Ekiti & 3 & 6.4 & 10 & 5.2 \\
\hline & Ikogosi-Ekiti & 0 & 0.0 & 10 & 5.2 \\
\hline \multirow[b]{2}{*}{ Ikole LGA } & Odo oro-Ekiti & 0 & 0.0 & 10 & 5.2 \\
\hline & Ikole-Ekiti & 8 & $\begin{array}{l}17 . \\
1\end{array}$ & 13 & 6.8 \\
\hline \multirow{2}{*}{$\begin{array}{l}\text { Ekiti } \\
\text { South- } \\
\text { West LGA }\end{array}$} & Ilawe-Ekiti & 0 & 0.0 & 10 & 5.2 \\
\hline & Igbara odo-Ekiti & 0 & 0.0 & 10 & 5.2 \\
\hline
\end{tabular}

URL: http://journals.covenantuniversity.edu.ng/index.php/cjbss 


\begin{tabular}{|l|l|l|l|l|l|}
\hline \multirow{2}{*}{$\begin{array}{l}\text { Ekiti East } \\
\text { LGA }\end{array}$} & Omuo-Ekiti & 3 & 6.4 & 10 & 5.2 \\
\cline { 2 - 6 } Gbonyin & Araromi-Ekiti & 0 & 0.0 & 10 & 5.2 \\
\cline { 2 - 6 } LGA & Agbado-Ekiti & 1 & 2.1 & 10 & 5.2 \\
\hline \multirow{3}{*}{ Oye LGA } & Ode-Ekiti & 0 & 0.0 & 10 & 5.2 \\
\cline { 2 - 6 } & Itaji-Ekiti & 0 & 0.0 & 10 & 5.2 \\
\hline \multirow{3}{*}{ Ikere LGA-Ekiti } & 6 & $\begin{array}{l}12 . \\
8\end{array}$ & 10 & 5.2 \\
\cline { 2 - 6 } & Fagbohun-Ekiti & 0 & 0.0 & 10 & 5.2 \\
\cline { 2 - 6 } & Ikere-Ekiti & 9 & 19. & 13 & 6.8 \\
\hline
\end{tabular}

The results for IB users on computer/smartphone ownership, frequency of use of IB, usage period, place of use, and means of awareness about IB are presented in Table 2. All the IB users owned computers/smartphones and used IB majorly monthly $(85.1 \%)$. The majority
(46.8\%) had been using IB for just between 1-2 years, which shows they were early adopters of IB. The majority $(80.9 \%)$ made use of IB from their homes. Awareness and use of IB by the older adults were majorly from their banks $(72.3 \%)$.

\begin{tabular}{|c|c|c|}
\hline \multicolumn{3}{|c|}{$\begin{array}{c}\text { Table 2. Frequency distribution of IB Users' } \\
\text { Computer/Smartphone Ownership }\end{array}$} \\
\hline & $\begin{array}{c}\text { Freq } \\
(\mathrm{N}=47)\end{array}$ & $\%$ \\
\hline \multicolumn{3}{|c|}{ Computer/smartphone ownership } \\
\hline Yes & 47 & 100.0 \\
\hline No & 0 & 0.0 \\
\hline \multicolumn{3}{|l|}{ IB frequency of use } \\
\hline Daily & 2 & 4.3 \\
\hline Weekly & 5 & 10.6 \\
\hline Monthly & 40 & 85.1 \\
\hline Quarterly & 0 & 0.0 \\
\hline Bi-annually & 0 & 0.0 \\
\hline Annually & 0 & 0.0 \\
\hline \multicolumn{3}{|l|}{ IB usage period } \\
\hline $1-2$ years & 22 & 46.8 \\
\hline $3-4$ years & 3 & 6.4 \\
\hline $5-6$ years & 11 & 23.4 \\
\hline Above 6 years & 11 & 23.4 \\
\hline \multicolumn{3}{|l|}{ Place of IB use } \\
\hline Home & 38 & 80.9 \\
\hline Workplace & 9 & 19.1 \\
\hline Cybercafé & 0 & 0.0 \\
\hline \multicolumn{3}{|c|}{ Means of IB awareness } \\
\hline Telephone/Radio & 0 & 0.0 \\
\hline Through the bank & 34 & 72.3 \\
\hline
\end{tabular}

URL: http://journals.covenantuniversity.edu.ng/index.php/cjbss 


\begin{tabular}{|l|l|l|}
\hline Newspapers & 0 & 0.0 \\
\hline $\begin{array}{l}\text { Leaflets/Advertiseme } \\
\text { nt }\end{array}$ & 0 & 0.0 \\
\hline Friends/Relations & 13 & 27.7 \\
\hline
\end{tabular}

Analysis of the data for respondents who were not using IB reveals that $60.4 \%$ did not have computers/smartphones as shown in Table 3. All the respondents also preferred the traditional banking system which made them not have acquired computers/smartphones which could make them use IB. Also, $90.1 \%$ of the non-IB user had been using the traditional banking system for more than six years, with most (73.5\%) using it monthly.

\begin{tabular}{|l|l|l|}
\hline $\begin{array}{l}\text { Table 3. Frequency distribution of Non-IB } \\
\text { Users toward Computer/Smartphone } \\
\text { ownership and banking system preference }\end{array}$ \\
\hline \multicolumn{1}{|c|}{ Measurements } & \multicolumn{1}{c|}{$\begin{array}{c}\text { Freq } \\
\text { (N=192) }\end{array}$} & $\%$ \\
\hline Computer/smartphone ownership \\
\hline Yes & 76 & 39.6 \\
\hline No & 116 & 60.4 \\
\hline Total & 192 & 100.0 \\
\hline Banking system preferred and use \\
\hline Internet banking & 0 & 0.0 \\
\hline $\begin{array}{l}\text { Traditional } \\
\text { banking }\end{array}$ & 192 & 100.0 \\
\hline Total & 192 & 100.0 \\
\hline Traditional banking length of use \\
\hline $1-2$ years & 0 & 0.0 \\
\hline $3-4$ years & 15 & 7.8 \\
\hline $5-6$ years & 0.0 & 0.0 \\
\hline Above 6 years & 173 & 90.1 \\
\hline Missing value & 4 & 2.1 \\
\hline Total & 192 & 100.0 \\
\hline Traditional banking frequency of use \\
\hline Daily & 1 & 0.5 \\
\hline Weekly & 16 & 8.3 \\
\hline Monthly & 141 & 73.5 \\
\hline Quarterly & 33 & 17.2 \\
\hline Bi-annually & 1 & 0.5 \\
\hline Annually & 0 & 0.0 \\
\hline Total & 192 & 100.0 \\
\hline
\end{tabular}

URL: http://journals.covenantuniversity.edu.ng/index.php/cjbss 


\subsection{Answers to the Research Questions}

This section provides answers to the five research questions.

Research Question 1: What is the mode of banking preferred among older adults?
The analysis in Table 4 shows that most of the older adults in Ekiti preferred the traditional banking system as only $19.7 \%$ of them used IB.

\begin{tabular}{|c|c|c|}
\hline & $\begin{array}{c}\text { Freq } \\
(\mathrm{N}=239)\end{array}$ & $\%$ \\
\hline Internet banking & 47 & 19.7 \\
\hline $\begin{array}{l}\text { Traditional } \\
\text { banking }\end{array}$ & 192 & 80.3 \\
\hline
\end{tabular}

Similarly, the interview responses reveal that majority of the respondents felt visiting bank branches for banking activity is better than online banking, even though some of the non-IB users complained of the inconveniences associated with visiting bank branches:

I have not heard about IB.

Even at that, I prefer to do banking activities physically at the bank. That is what I have been doing since I was twenty years old. I am now 78 years. I don't think I want to try another method. (Respondent 7, male, nonIB user, Ijero LGA)

I prefer carrying out my banking transactions at the bank because I do not know how to use the computer or phone very well (Respondent 13, female, non-IB user, Ikere LGA).

To me, going to the bank wastes time and is strenuous. I only go to bank premises to deposit money or use the ATM. I can do other transactions online through IB
(Respondent 20, male, IB user, Ado Ekiti LGA).

On the preference of banking system by the older population, our results are in line with many previous studies such as Camilleri and Grech (2017), Asmi and Ishaya (2012), Ifezue, Ama and Moseki (2016), Mattila et al. (2003) who also found that most elderly people prefer visiting bank branches regularly for their banking activities rather than using online banking. Most of the elderly population are skeptical of online banking due to the faceless banking system where security is a big challenge. They prefer physical interactions at the bank where they feel more secured than the faceless IB platforms. Our findings further show that the few elderly IB users sampled were not even prolific users of IB as they used it monthly, which may be because most of them are retirees who collect pensions on a monthly basis.

Research Question 2: What is the frequency of IB usage among the older population?

Findings show that the older adults were not prolific users of IB as a majority $(85.1 \%)$ used the technology monthly as 
shown in Table 3. Responses from the interview also corroborate this finding:

I always transfer money to my son in school every month. I use IB for the transfer (Respondent 11, male, IB user, Oye LGA).

I use IB monthly (Respondent 16, male, IB user, Ikere LGA).

I mostly use IB monthly when I need to check for my pension if it has been paid. (Respondent 5, female, IB user, Ikole LGA).

Daily (Respondent 3, female, IB user, Ijero LGA).

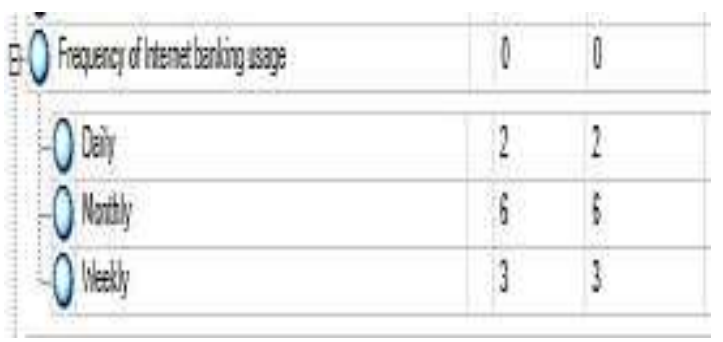

I use it every week (Respondent 6, male, IB user, Ikole LGA).

.... monthly (Respondent

15 , male IB user, Ikere LGA).

Monthly (Respondent 17, female IB user, Ado-Ekiti LGA).

Daily (Respondent 18, male, IB user, Oye LGA).

The screenshot of thematic analysis and word cloud representation and a screenshot of the answers categories from the Nvivo software are presented in Figure 1. The word 'monthly' came out boldly, which shows it has the highest frequency.

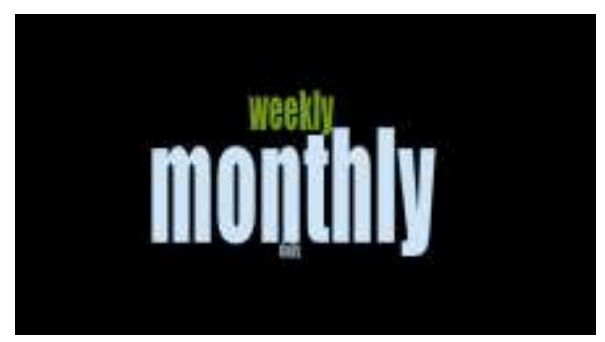

Figure 1. Screenshot of thematic analysis showing the frequency of IB usage and the word cloud representation

\section{Research Question 3: Which feature(s) of IB is/are mostly used by older adults?}

The analysis shown in Table 5 reveals that funds transfer is the most used feature of IB by the older adults, (mean score 3.69), followed by bills payment (3.58), account enquires/reports (2.96), and purchase of airtime and data bundle (2.40). Other features were not used by them. These findings corroborate the findings of Chauhan and Choudhary (2015), Kumar, Reddy and Sreenivasulu (2017), and Senali (2017). This also shows the limitation of the use of IB by the older adults as they indicated they did not use many features available on the IB platforms. For the fact that the adults may not have advanced skills at using IT, their use of IB features is limited to the basic one. 
Table 5. Descriptive Analysis of Features of IB used by Older Adults

\begin{tabular}{|l|l|l|l|l|l|l|}
\hline & \multirow{2}{*}{$\begin{array}{l}\text { Low use } \\
\text { Items }\end{array}$} & $\begin{array}{l}\text { Averagely } \\
\text { used } \\
\text { (Freq/\%) }\end{array}$ & $\begin{array}{l}\text { Highly } \\
\text { used } \\
\text { (Freq/\%) }\end{array}$ & Missing & Valid & \\
\hline $\begin{array}{l}\text { Funds Transfer (sending money } \\
\text { from one account to another) }\end{array}$ & $6(12.8 \%)$ & $\begin{array}{l}7 \\
(14.9 \%)\end{array}$ & $3268.1 \%)$ & 2 & 45 & 3.69 \\
\hline $\begin{array}{l}\text { Bill Payment (settlement of cable } \\
\text { television subscription, electricity } \\
\text { bill, etc.) }\end{array}$ & $5(10.6 \%)$ & $\begin{array}{l}12 \\
(25.5 \%)\end{array}$ & $\begin{array}{l}26 \\
(55.4 \%)\end{array}$ & 4 & 43 & 3.58 \\
\hline $\begin{array}{l}\text { Account/Transaction Enquiries/ } \\
\text { Reports }\end{array}$ & $15(31.9 \%)$ & $\begin{array}{l}22 \\
(46.8 \%)\end{array}$ & $9(19.2 \%)$ & 1 & 46 & 2.96 \\
\hline $\begin{array}{l}\text { Purchase of Airtime and Data } \\
\text { bundle }\end{array}$ & $44(93.6 \%)$ & $2(4.3 \%)$ & $0(0.0 \%)$ & 1 & 46 & 2.40 \\
\hline Card and Cheque Services & $0(0.0 \%)$ & $0(0.0 \%)$ & $0(0.0 \%)$ & 0 & 0 & 0.0 \\
\hline Travel booking and payment & $0(0.0 \%)$ & $0(0.0 \%)$ & $0(0.0 \%)$ & 0 & 0 & 0.0 \\
\hline Foreign exchange transactions & $0(0.0 \%)$ & $0(0.0 \%)$ & $0(0.0 \%)$ & 0 & 0 & 0.0 \\
\hline Stock and Investments & $0(0.0 \%)$ & $0(0.0 \%)$ & $0(0.0 \%)$ & 0 & 0 & 0.0 \\
\hline Loan Application & $0(0.0 \%)$ & $0(0.0 \%)$ & $0(0.0 \%)$ & 0 & 0 & 0.0 \\
\hline Online/Video chat & $0(0.0 \%)$ & $0(0.0 \%)$ & $0(0.0 \%)$ & 0 & 0 & 0.0 \\
\hline Modification of account profile & $0(0.0 \%)$ & $0(0.0 \%)$ & $0(0.0 \%)$ & 0 & 0 & 0.0 \\
\hline Standing order & $0(0.0 \%)$ & $0(0.0 \%)$ & $0(0.0 \%)$ & 0 & 0 & 0.0 \\
\hline Customer feedback & $0(0.0 \%)$ & $0(0.0 \%)$ & $0(0.0 \%)$ & 0 & 0 & 0.0 \\
\hline Others (please specify) & $0(0.0 \%)$ & $0(0.0 \%)$ & $0(0.0 \%)$ & 0 & 0 & 0.0 \\
\hline
\end{tabular}

The interview responses also supported these findings:

I use IB to transfer money and pay PHCN bills regularly (Respondent 1, male IB user, Ijero LGA).

I use it majorly for fund transfer and bill payment services (Respondent 3, female, IB user, Ijero LGA).

Cash transfer and payment of PHCN bills (Respondent 5, female, IB user, Ikole LGA).

Voucher top-up and fund transfer services (Respondent 6, male, IB user, Ikole LGA).

Transfer of money, standing order. I also use it to change my ATM pin, pay for my electricity bills, and check my account balance (Respondent 11, male, IB user, Oye LGA).
Fund transfer and airtime voucher top-up (Respondent 15, male, IB user, Ikere LGA). Funds transfer, obtaining a statement of account, and bill payment (Respondent 16, male, IB user, Ikere LGA).

Sending money (Respondent 17, female, IB user, Ado-Ekiti LGA).

..... to transfer money and buy credit for my phone (Respondent 18, male, IB user, Oye LGA).

Figure 2 shows the screenshot of thematic analysis showing features of IB used by the older adults and the word cloud representation. The words, fund transfer, bill payment, and voucher topup are displayed clearly. 

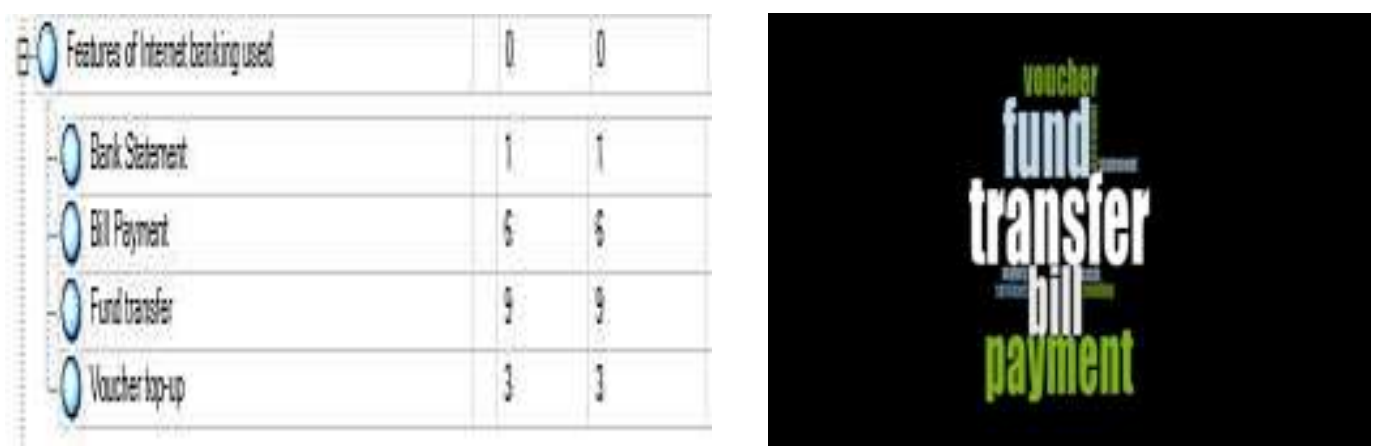

Figure 2. Screenshot of thematic analysis showing the frequency of features used and the word cloud representation

\section{Research Question Four: What are the} reasons for the use of $I B$ by the adopters?

Table 6 presents some of the reasons that made older adults use IB. The results show that they had positive attitudes toward IB as most of them $(89.3 \%)$ agreed that using IB is a good and wise idea. Most of them used IB because of ease of access and use of IB $(87.3 \%)$, opportunity to carry out banking transaction anytime and anywhere $(85.1 \%)$, the convenience associated with using IB (83.0\%), costsaving in using IB (80.9\%), banks' encouragements $(80.8 \%)$, encouragement from family and friends (71.1\%), possession of the knowledge and resources necessary to use internet banking (65.9\%), and assurance of protection and security from banks (61.7\%).

\begin{tabular}{|c|c|c|c|c|c|}
\hline Reasons for using IB & $\begin{array}{c}\text { SD } \\
(\text { Freq/\%) }\end{array}$ & $\begin{array}{c}\text { D } \\
(\text { Freq/\%) }\end{array}$ & $\begin{array}{c}\mathrm{U} \\
(\text { Freq/\%) }\end{array}$ & $\begin{array}{c}\mathrm{A} \\
(\text { Freq/\%) }\end{array}$ & $\begin{array}{c}\text { SA } \\
(\text { Freq } / \%)\end{array}$ \\
\hline $\begin{array}{l}\text { I feel using Internet banking is a } \\
\text { good and wise idea }\end{array}$ & $\begin{array}{l}1 \\
(2.1 \%)\end{array}$ & $\begin{array}{l}2 \\
(4.3 \%)\end{array}$ & 2 & $\begin{array}{l}30 \\
(63.8 \%)\end{array}$ & $\begin{array}{l}12 \\
(25.5 \%)\end{array}$ \\
\hline $\begin{array}{l}\text { Internet banking is easy to access } \\
\text { and use and also help helps me to } \\
\text { accomplish banking activities } \\
\text { faster }\end{array}$ & $\begin{array}{l}1 \\
(2.1 \%)\end{array}$ & $\begin{array}{l}0 \\
(0.0 \%)\end{array}$ & $\begin{array}{l}5 \\
(10.6 \%)\end{array}$ & $\begin{array}{l}21 \\
(44.7 \%)\end{array}$ & $\begin{array}{l}20 \\
(42.6 \%)\end{array}$ \\
\hline $\begin{array}{l}\text { Internet banking is convenient for } \\
\text { me to use }\end{array}$ & $\begin{array}{l}0 \\
(0.0 \%)\end{array}$ & $\begin{array}{l}0 \\
(0.0 \%)\end{array}$ & $\begin{array}{l}8 \\
(17.0 \%)\end{array}$ & $\begin{array}{l}26 \\
(55.3 \%)\end{array}$ & $\begin{array}{l}13 \\
(27.7 \%)\end{array}$ \\
\hline $\begin{array}{l}\text { Internet banking saves time and } \\
\text { cost of transactions }\end{array}$ & $\begin{array}{l}0 \\
(0.0 \%)\end{array}$ & $\begin{array}{l}8 \\
(17.0 \%) \\
\end{array}$ & $\begin{array}{l}1 \\
(2.1 \%)\end{array}$ & $\begin{array}{l}24 \\
(51.1 \%)\end{array}$ & $\begin{array}{l}14 \\
(29.8 \%)\end{array}$ \\
\hline $\begin{array}{l}\text { I use Internet banking because of } \\
\text { my bank encouragement }\end{array}$ & $\begin{array}{l}1 \\
(2.1 \%)\end{array}$ & $\begin{array}{l}5 \\
(10.6 \%)\end{array}$ & $\begin{array}{l}3 \\
(6.4 \%)\end{array}$ & $\begin{array}{l}23 \\
(48.9 \%) \\
\end{array}$ & $\begin{array}{l}15 \\
(31.9 \%)\end{array}$ \\
\hline $\begin{array}{l}\text { Internet banking gave me the } \\
\text { opportunity to carry out } \\
\text { transactions at any time and any } \\
\text { place }\end{array}$ & $\begin{array}{l}1 \\
(2.1 \%)\end{array}$ & $\begin{array}{l}6 \\
(12.8 \%)\end{array}$ & $\begin{array}{l}0 \\
(0.0 \%)\end{array}$ & $\begin{array}{l}19 \\
(40.4 \%)\end{array}$ & $\begin{array}{l}21 \\
(44.7 \%)\end{array}$ \\
\hline $\begin{array}{l}\text { My family/friends encourage me } \\
\text { to use Internet banking }\end{array}$ & $\begin{array}{l}0 \\
(0.0 \%)\end{array}$ & $\begin{array}{l}1 \\
(2.2 \%)\end{array}$ & $\begin{array}{l}12 \\
(26.7 \%)\end{array}$ & $\begin{array}{l}23 \\
(51.1 \%)\end{array}$ & $\begin{array}{l}9 \\
(20.0 \%)\end{array}$ \\
\hline $\begin{array}{l}\text { I have the knowledge and } \\
\text { resources necessary to use Internet }\end{array}$ & $\begin{array}{l}0 \\
(0.0 \%)\end{array}$ & $\begin{array}{l}1 \\
(2.1 \%)\end{array}$ & $\begin{array}{l}15 \\
(31.9 \%)\end{array}$ & $\begin{array}{l}22 \\
(46.8 \%)\end{array}$ & $\begin{array}{l}9 \\
(19.1 \%)\end{array}$ \\
\hline
\end{tabular}

URL: http://journals.covenantuniversity.edu.ng/index.php/cjbss 


\begin{tabular}{|l|l|l|l|l|l|}
\hline banking & & & & & \\
\hline $\begin{array}{l}\text { My bank assures me of maximum } \\
\text { protection at all times on Internet } \\
\text { banking platform }\end{array}$ & $\begin{array}{l}0 \\
(0.0 \%)\end{array}$ & $\begin{array}{l}13 \\
(27.7 \%)\end{array}$ & $\begin{array}{l}5 \\
(10.6 \%)\end{array}$ & $\begin{array}{l}22 \\
(46.8 \%)\end{array}$ & $\begin{array}{l}7 \\
(14.9 \%)\end{array}$ \\
\hline
\end{tabular}

From the interview conducted with some respondents who were users of IB, it was noted that several reasons made them use IB as shown in Figure 3. However, the majority of the respondents actually stated that they used IB because of its convenience. Some of the responses:

It is convenient (Respondent 1, male IB user, Ijero LGA).

It is convenient for me; it takes less time. I don't need to spend money on transport fare to the bank and waste time queuing up (Respondent 3, female, IB user, Ijero LGA).

It relieves me from the stress of visiting the bank often. I can use my phone to send money or check my account balance. (Respondent 5, female, IB user, Ikole LGA).

It is safe and convenient; also, it relieves me from the stress of going to the bank halls (Respondent 6, male, IB user, Ikole LGA).

It does not give me any stress; it is transparent and makes my banking transactions easy to perform (Respondent 11, male, IB user, Oye LGA).
It saves me transport fares to the bank and it is simple to use. I can use it anywhere; it is easy to operate, convenient and very fast. Besides, it saves me time and energy (Respondent 15, male, IB user, Ikere LGA).

To me, it is easy to use for business. Most of my customers transfer money to my account. I can easily check my balance. I also do transfer to my customers I buy goods from in Lagos. It is really convenient for me unlike in the olden days where I had to be going to the bank to deposit or withdraw money, or check account balances (Respondent 16, male, IB user, Ikere LGA).

It helps me perform my banking transactions with ease; it saves me time. I hardly visit the bank these days, more so that there is an ATM point near my house (Respondent 17, female, IB user, Ado-Ekiti LGA).

It is very convenient for me and it is easy for me; it saves time (Respondent 18, male, IB user, Oye LGA).

It does not waste much time; not strenuous and it can be performed at a customer's convenient time (Respondent 20, male, IB user, Ado-Ekiti LGA). 


\begin{tabular}{|c|c|c|}
\hline 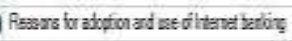 & 8 & 0 \\
\hline Cashleas & 1 & 1 \\
\hline Coweiar & 6 & 6 \\
\hline Eas Trersacbon & 5 & 5 \\
\hline Fast serisetalval & 2 & 3 \\
\hline NoQuase & 3 & 3 \\
\hline Norggiarvisitbbat: & 1 & 1 \\
\hline 105 reas & 3 & 3 \\
\hline Sare Eraty & 1 & 1 \\
\hline O SaveTine & 6 & 6 \\
\hline Sane Trarsporfare & 1 & 1 \\
\hline O Saxred & 4 & 5 \\
\hline OSirpe & 2 & 2 \\
\hline
\end{tabular}

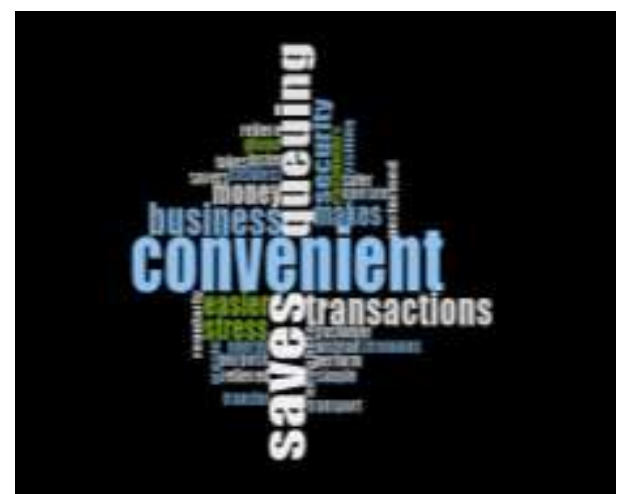

Figure 3: Screenshot of thematic analysis showing reasons for IB usage and the word cloud representation

The study can identify some reasons that made the older adults use IB, which could be summarised as positive attitude, ease of access and use, perception of usefulness, convenience, cost-saving, subjective norms or social influence, self-efficacy, as well as security. The interview responses also identify benefits such as convenience, time-saving, cashless transactions, ease of use, transparency, security, as well as any place and anytime banking, among others. These are in line with the findings of some previous studies such as Ahmed (2016), Appiah and HayfronAcquah (2016), Fadare (2016), Jham (2016), Jolly (2016), Lee (2009), Martins, Oliveira and Popovič (2014), Mukhtar (2015), Tarhini, El-Masri, Ali and Serrano (2016). In Georgieva (2018) study, the elders identified the need to be sociable, ease of use, safety, cheaper broadband, training, easy accessibility, easy user interface, and higher awareness as dominant determining factors for using IB. Arenas-Gaitán, Peral-Peral, RamÓnJerÓnimo (2015) results also show that the perception of usefulness and ease of use are some of the reasons that significantly made elderly people use IB. As a result of the fragility and health status of older adults, IB is a tool of convenience, as it can help the adults avoid having to go to the banks' branches to wait for long hours on queues before performing financial transactions. Hence, banks need to make the IB platforms easy to understand and use so this population could be able to use them with little or no assistance.

\section{Research Question Five: What are the reasons for the non-use of IB by the non-adopters?}

The analysis of the responses (Table 7) concerning the reasons why the elderly were not using IB reveals that a high percentage $(80.2 \%)$ indicated that they had not heard about it, while the same percentage $(80.2 \%)$ also indicated that they did not use IB because of not knowing the benefits they can derive from using IB. Few of the respondents $(16.7 \%)$ indicated they were not using IB because they had no money to buy computers/smartphones/modems. About $18.0 \%$ did not use it because they did not have the facilities (smartphones/computers) to use it, 
$15.6 \%$ indicated they did not know how to use computers and smartphones, while $13.5 \%$ were simply not interested in using IB. Hence, lack of awareness of IB and its benefits is the major reason for not using IB by the older adults. Other reasons are dislike, fear of insecurity, lack of interest, and knowledge of IT and resources.

\begin{tabular}{|c|c|c|}
\hline Reasons (I do not use IB because :) & $\begin{array}{c}\text { Yes } \\
(\text { Freq/\%) }\end{array}$ & $\begin{array}{c}\text { No } \\
(\text { Freq/\%) }\end{array}$ \\
\hline I have not heard about it & $119(62.0 \%)$ & $73(38.0 \%)$ \\
\hline I have no money to buy computer/smartphon & $32(16.7 \%)$ & $160(83.3 \%)$ \\
\hline $\begin{array}{l}\text { I do not have the facilities } \\
\text { (smartphones/computers) to use it. }\end{array}$ & $34(17.7 \%)$ & $158(82.3 \%)$ \\
\hline $\begin{array}{l}\text { I have no knowledge to use } \\
\text { computer/smartphone. }\end{array}$ & $30(15.6 \%)$ & $162(84.4 \%)$ \\
\hline I am not interested in using it. & $72(37.5 \%)$ & $120(62.5 \%)$ \\
\hline $\begin{array}{l}\text { I don't know its benefits or importance to } \\
\text { me. }\end{array}$ & $106(55.2 \%)$ & $86(44.8 \%)$ \\
\hline $\begin{array}{l}\text { I prefer going to the bank to have physical } \\
\text { interactions with bank officials. }\end{array}$ & $66(34.4 \%)$ & $126(65.6 \%)$ \\
\hline
\end{tabular}

Responses from the interview reveal that most of the non-IB users $(62.0 \%)$ were not aware of IB, while about $55.0 \%$ were not aware of its benefits. Some also preferred visiting the bank for their financial transactions $(34.4 \%)$. Some others were simply not interested $(37.5 \%)$, did not have the facilities to use IB (17.7\%), and did not have the knowledge to use computers or smartphones (15.6\%). The interview responses corroborated some of the questionnaire responses as presented in the responses and the word cloud representation screenshots (Figure 4):

I do not have an interest in it

(Respondent 2, male, non-IB

User, Ijero LGA).

I have not heard about it (Respondent 7, male, non-IB user, Ijero LGA).

I do not use IB because I have heard about people who lost their money through it (Respondent 8, female, non-IB user, Ikole LGA). I dislike it because I heard one must be able to use a computer very well and one will need to be buying credits on the phone before one can use it. I don't think I will be able to afford that. (Respondent 9, male, non-IB user, Oye LGA).

I am unaware of it. My bank has not told me about it. I don't know what I can use it for (Respondent 10, male, non-IB user, Oye LGA). My account officer at my bank has told me about it but I don't think I can use it because I really do not know how to use the computer very well. More so, I only visit the branch once a month when I need to collect my pension so I don't think I need it (Respondent 13, female, non-IB user, Ikere LGA).

I don't like it because I am not sure of its security (Respondent

URL: http://journals.covenantuniversity.edu.ng/index.php/cjbss 
14, male, non-IB user, Ikere LGA).

I don't think I have heard about it.

Can you tell me how to use it?
(Respondent 19, female, non-IB user, Ijero LGA).

\begin{tabular}{|c|c|c|c|}
\hline O Reasuss for weratofor ard use of htened barbing & a & a & \\
\hline Dsileferavioe & 4 & 4 & 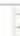 \\
\hline Drthontalias & 1 & 1 & - \\
\hline Fear of bsing rorel & 1 & 1 & - \\
\hline haderuate Sexait & 2 & 2 & - \\
\hline Wabelexenteserise & 1 & 1 & - \\
\hline -O haCorpts lasadedyeor Sill & 1 & 2 & 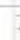 \\
\hline 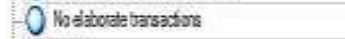 & 1 & 1 & - \\
\hline Wh Wrer & 1 & 1 & - \\
\hline O laphsisal irteraciars & 1 & 1 & 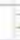 \\
\hline -O katine & 1 & 1 & 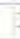 \\
\hline Nat hterested & 2 & 2 & 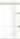 \\
\hline Nit Popular & 1 & 1 & 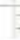 \\
\hline Proneb Frad & 1 & 1 & . \\
\hline Sressid & 1 & 1 & $y$ \\
\hline -0 Uhenare & 4 & 4 & \\
\hline
\end{tabular}

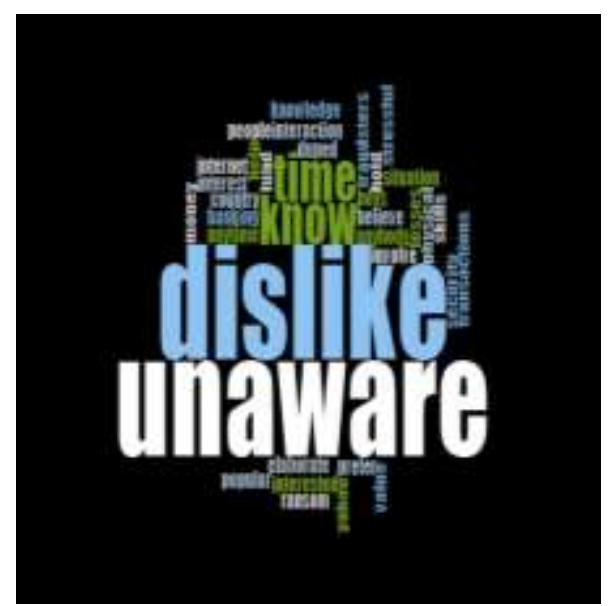

Figure 4. Screenshot of thematic analysis showing reasons for non-use of IB and the word cloud representation.

The word cloud in Figure 4 reveals that words such as unaware, dislike, no time, no knowledge, no interest, and security, are some of the major reasons, stated by the older adults interviewed. These findings corroborate the findings of many previous studies. For instance, Odiboh, Oresanya \& Ekanem (2016) found a low level of awareness about ebanking among their respondents in Ogun State, Nigeria. Tarhini, Mgbemena, Trab and Masa'Deh (2015) also found that majority of their elderly respondents were not using IB because they were not aware of the benefits, while some thought IB was too complex to use or of little or no relevance to them. Lichtenstein and Williamson (2006) also identified a lack of awareness toward IB and its advantages, inadequate knowledge lack of trust, security, and high perceived privacy risks, among other factors. Tarhini et al. (2015) also found that fear of fraud was a great concern among the customers which brought about distrust in banking activities over the Internet. Awara and Anyadighibe (2014), Mukhtar (2015), and Sohail and Shanmugham (2004) observed that the older respondents they studied were not convenient with the use of IB due to low level of awareness, sensitisation, fear of fraud and resistance to change. Kumar, et al. (2017) also found that lack of knowledge, fund, and time by customers towards IB were some of the reasons why the technology was not used by some older adults. Ronning and Solvberg's (2017) findings also show that older adults were reluctant to use IB because they felt they might not cope in learning and mastering how to use the service as a result of low self-efficacy. 
Piiparinen (2014) found that seniors were not willing to use online banks, because they did not have access or knowledge to use the technology coupled with their physical conditions. This is in line with the opinion of Jeong and Yoon (2013) that a skillful person with high knowledge of computing may rate IB as easier to use than an individual who has relatively little knowledge of computing. Mattila et al. (2003) found that perceived difficulty in using computers combined with the lack of personal service in e-banking, confusing web pages and complex steps, difficulties with computers and Internet in general, as well as security issues were the main barriers of IB adoption among older adults, which they blamed on insufficient or non-existent of training on how to use IB technology. Azam, Qiang and Sharif, (2013) stated that older adults were skeptical of transactions that are carried out with no physical interaction; hence, they had no or very little trust in it. Senali (2017) identified fear of hackers, lack of knowledge, psychological decline, and limitations of technology as barriers to mobile banking adoption among senior citizens in Australia. Also, in a study by Al-Fahim (2013), some customers avoid using electronic banking because of the perceived proneness to fraud and inadequate protection on account information. In fact, security concerns have been indicated by much past research to influence usage intentions of IB not only directly but also indirectly. Some older adults were also fearful due to negative word-of-mouth and bad experience from some IB users as stated in the study of Malhotra (2016).
In addition, Rock et al. (2010) show that older respondents in the USA were less likely to use the Internet as a source of financial information, not for security concerns, but because they preferred contact with bank workers due to websites being difficult or confusing. Also, the lack of physical interaction was mentioned as one of the important factors for not using IB, which corroborates the findings of Asmi and Ishaya (2012). The adults could fear the risk of losing their physical bank to an online bank, depriving them of valued human interaction. Going to the bank premises could be seen as a form of relieving boredom for some of the older adults who most of the time do not have any relatives living with them. The need for human interaction, the need to be sociable, and the need to engage them in an in-person communication to preserve cognitive functions are important to the elders. Hence, banks should ensure the elders have account officers who regularly interact with the adults.

Our findings further reveal that banks in Ekiti state had not created adequate awareness or enough sensitisation about IB and its numerous benefits to this population. Since most older users are less familiar with the technology, their ability to adopt new technology depends on the provision of adequate information about the benefits of the technology to them, their willingness, computer self-efficacy, and dependence on prior knowledge. Hence, promoters of technology adoption among this population should take cognisance of the fact that they have lower confidence in their cognitive capabilities, and that they often act as a self-fulfilling 
prophecy when adopting new technologies (Yousafzai \& Yani-de-Soriano, 2012). Banks, therefore, should typically devote efforts towards raising enough awareness about IB, promoting its benefits among this population. There is also the need to provide the elderly users with assistance, access to computing devices, with suitable training, and also build their confidence in IB by highlighting the security features available on IB platforms.
Research Question Six: Do non-IB users have the intention of using in the future?

The results, as shown in Table 8, reveal that the non-IB users have the intention to use IB, as about two-thirds of them $(64.1 \%)$ agreed to use IB anytime soon and in the future $(59.9 \%)$. The item ' $I$ am ready to use IB anytime soon' has the highest mean score (3.38), while the item of 'I may consider using $I B$ in the future if my friends/family/children encourage me' was ranked lowest with a mean value of 1.86 .

\begin{tabular}{|l|l|l|l|l|l|l|}
\hline \multicolumn{7}{|c|}{ Table 8: Descriptive Analysis of Intention/Readiness to Use IB by the Older Adults } \\
\hline \multicolumn{1}{|c|}{ Intentions/Readiness } & $\begin{array}{c}\text { SD } \\
\text { (Freq/\%) }\end{array}$ & $\begin{array}{c}\text { D } \\
\text { (Freq/\%) }\end{array}$ & $\begin{array}{c}\text { U } \\
\text { (Freq/\%) }\end{array}$ & $\begin{array}{c}\text { A } \\
\text { (Freq/\%) }\end{array}$ & $\begin{array}{c}\text { SA } \\
\text { (Freq/\%) }\end{array}$ & Mean \\
\hline $\begin{array}{l}\text { I am ready to use IB } \\
\text { anytime soon }\end{array}$ & $\begin{array}{l}15 \\
(7.8 \%)\end{array}$ & $\begin{array}{l}13 \\
(6.8 \%)\end{array}$ & $\begin{array}{l}41 \\
(21.3 \%)\end{array}$ & $\begin{array}{l}89 \\
(46.4 \%)\end{array}$ & $\begin{array}{l}34 \\
(17.7 \%)\end{array}$ & 3.38 \\
\hline $\begin{array}{l}\text { I would like to use IB in } \\
\text { the future }\end{array}$ & $\begin{array}{l}14 \\
(7.3 \%)\end{array}$ & $\begin{array}{l}14 \\
(7.3 \%)\end{array}$ & $\begin{array}{l}49 \\
(25.5 \%)\end{array}$ & $\begin{array}{l}92 \\
(47.9 \%)\end{array}$ & $\begin{array}{l}23 \\
(12.0 \%)\end{array}$ & 3.29 \\
\hline $\begin{array}{l}\text { I may consider using IB } \\
\text { in the future if I am able } \\
\text { to acquire } \\
\text { Internet/Computer skills }\end{array}$ & $\begin{array}{l}17 \\
(8.9 \%)\end{array}$ & $\begin{array}{l}35 \\
(18.2 \%)\end{array}$ & $\begin{array}{l}46 \\
(24.0 \%)\end{array}$ & $\begin{array}{l}75 \\
(39.0 \%)\end{array}$ & $\begin{array}{l}19 \\
(9.9 \%)\end{array}$ & 3.21 \\
\hline $\begin{array}{l}\text { I may consider using IB } \\
\text { in the future if my } \\
\text { security is guaranteed }\end{array}$ & $\begin{array}{l}46 \\
(24.9 \%)\end{array}$ & $\begin{array}{l}99 \\
(51.6 \%)\end{array}$ & $\begin{array}{l}25 \\
(13.0 \%)\end{array}$ & $\begin{array}{l}9 \\
(4.7 \%)\end{array}$ & $\begin{array}{l}13 \\
(6.8 \%)\end{array}$ & 2.17 \\
\hline $\begin{array}{l}\text { I may consider using IB } \\
\text { in the future if my } \\
\text { friends/family/children } \\
\text { encourage me }\end{array}$ & $\begin{array}{l}79 \\
(41.1 \%)\end{array}$ & $\begin{array}{l}83 \\
(43.2 \%)\end{array}$ & $\begin{array}{l}12 \\
(6.3 \%)\end{array}$ & $\begin{array}{l}7 \\
(3.7 \%)\end{array}$ & $\begin{array}{l}11 \\
(5.7 \%)\end{array}$ & 1.86 \\
\hline
\end{tabular}

The results show that the non-IB users have the intention to use IB, hence the need for banks to create more awareness about IB, especially among the older population. Banks could deploy the use of account officers who will interact with the adults one-on-one to make them have a proper understanding of the benefits they could derive from using IB even as they age gracefully.

\section{Conclusion and Contributions to Knowledge}

Elderly people are growing population which present different characteristics from the rest of the population. They are fragile and need assistance, therefore, need assisted technologies such as IB,

URL: http://journals.covenantuniversity.edu.ng/index.php/cjbss 
which our study has confirmed. Theoretically, this study contributes to knowledge in the area of adoption and use of IB among older adults in Nigeria by revealing low usage of IB among the older population in Nigeria and also identifying reasons why older adults use or not use IB. The study also confirms the findings of previous studies about the low usage of IB among the elderly. Besides, this study provides academicians and researchers with empirical data in pursuance of further studies on e-banking, most especially IB. The findings of this study also provide relevant practical data and information that could help banks build a stronger customer relationship management by paying more attention to the aging population and intensify efforts in the area of awareness and sensitisation of this population for them to be well informed and not misinformed about IB. Besides, this study provides information to banks and other stakeholders about customers' concerns toward inadequate security and poor Internet service which makes older adults not to want to use IB and which could jeopardise the CBN vision 2020, if quick attention is not taken to tackle these challenges.

\section{Recommendations and Suggestions for Further Studies}

Based on the findings of this study, it is recommended that banks should intensify efforts toward adequate

\section{References}

Al-Fahim, N. H. (2013). An exploratory study of factors affecting the internet banking adoption: A awareness and sensitisation of older adults on the benefits associated with the use of IB. There should also be sensitisation on the availability of security when using IB to build the trust of the adults about IB use. Banks should improve on the design and development of IB platforms to make navigation through the webpages easy for older adults who may have problems with eye sights and shaky hands. Besides, government and telecommunication companies could encourage the use of IB among older adults by ensuring that resources such as Internet access tariff plans, modems, smartphones, and computers needed are affordable. Besides, older adults could be encouraged by making these facilities available to them at reduced or discounted rates.

This study focused only on nine LGAs in Ekiti State with consideration of two towns from each LGA; effort should be made to include other towns and LGAs not included in this study in future studies. This study could also be extended to other states in Nigeria. The instruments for data collection are questionnaires and interviews, future studies could consider focus group discussion by meeting respondents (older adults) together as a group, either at pensioners' houses, association meetings or club meetings to further give insights to diverse opinions from them.

$$
\begin{array}{lcr}
\text { qualitative } & \text { study } & \text { among } \\
\text { postgraduate } & \text { students, Global } \\
\text { Journal of } & \text { Management and }
\end{array}
$$


Business Research Finance, 13, 8, 22-32.

Ahmed, E. M. (2016). Factors influencing the adoption of internet banking in Malaysia, Journal of Internet Banking and Commerce, 21, 1, 1-28.

Ainin, S., Lim, C.H., \& Wee, A. (2005) Prospects and challenges of ebanking in Malaysia, The Electronic Journal of Information Systems in Developing Countries, 22, 1, 1-11.

Aliyu, A. \& Tasmin, R. (2012). The impact of information and communication technology on banks' performance and customer service delivery in banking industry, International Journal of Latest Trends in Finance \& Economic Sciences, 2, 1, 80-87.

Appiah, B. \& Hayfron-Acquah, J. B. (2016). Examining the factors affecting internet banking adoption in Ghana: The customers' perspective, Unpublished MPhil thesis, Institute of Distance Learning, Kwame Nkrumah University of Science and Technology, Ghana; retrieved May 20, 2019

http://dspace.knust.edu.gh/bitstream/123 456789/9982/1/BRIGHT\%20AP PIAH.pdf

Arenas-Gaitán, J., Peral-Peral, B., \& RamÓn-JerÓnimo, M. A. (2015). Elderly and internet banking: An application of UTAUT2, Journal of Internet Banking and Commerce, 20, 1, 1-23; retrieved August 10, 2019 from http://www.arraydev.com/comme rce/jibc/
Ashour, Y. H. \& Badah, W. N. (2010). Customer adoption of internet banking in Gaza strip, Unpublished MBA thesis, The Islamic University of Gaza, Deanery of Graduate Study, Palestine; retrieved August 17, 2019 from https://iugspace.iugaza.edu.ps/bits tream/handle/20.500.12358/1677 5/file_1.pdf?sequence $=1 \&$ isAllo wed $=\mathrm{y}$

Asmi, F. \& Ishaya, T. (2012). Understanding the behavior of the elderly towards Internet banking in the UK, SOTICS 2012: The Second International Conference on

Social Eco-Informatics, 100-106.

Azam, A., Qiang, F., \& Sharif, S. (2013). Personality based psychological antecedents of consumers' trust in e-commerce, Journal of WEI Business and Economics, 2, 1, 31-40.

Barnard, Y., Bradley, M., Hodgson, F., \& Lloyd, A. (2013) Learning to use new technologies by older adults: Perceived difficulties, experimentation behaviour and usability, Computers in Human Behaviour, 29, 4, 1715-1724.

Berkowsky, R., Sharit, J., \& Czaja, S. (2018). Factors predicting decisions about technology adoption among older adults, Innovation in Aging, 1-12. doi:10.1093/geroni/igy002

Braganza, P. I. \& Mekoth, N. (2017) Intention to use internet banking: Differences between users and non-users and the moderating role of felt want, Unpublished $\mathrm{PhD}$ 
thesis, Goa University, Taligao Gao, India.

Camilleri, S. J. \& Grech, G. (2017). The relevance of age categories in explaining internet banking adoption rates and customers' attitudes towards the service, Journal of Applied Finance and Banking, 7, 2, 29-47; retrieved April 20, 2019 from SSRN: https://ssrn.com/abstract=293479 0

CBN (2014). Payments system transformation: Cashless Nigeria implementation; retrieved June 11, 2018 from https://www.cbn.gov.ng/cashless/ New\%20Payment\%20Systems.pd $\mathrm{f}$

Chauhan, V. \& Choudhary, V. (2015). Internet banking: Challenges and opportunities in Indian context. Journal of Management Sciences and Technology, 2, 3, 29-40.

Czaja, R. (1998) Questionnaire pretesting comes of age, Marketing Bulletin, 9, 52-66.

Ding, X., Verma, R., \& Iqbal, Z. (2007). Self-service technology and online financial service choice, International Journal of Service Industry Management, 18, 3, 24668; retrieved July 21 from http://dx.doi.org/10.1108/095642 30710751479

Delello, J. A. and McWhorter, R. R. (2017). Reducing the digital divide: Connecting older adults to iPad technology, Journal of Applied Gerontology, 36, 1, 3-28, doi: $10.1177 / 0733464815589985$

DutchNews (December 10, 2019). Internet savvy elderly still prefer cash, don't trust internet banking, SocietyTech \& Media; retrieved June 9, 2019 from https://www.dutchnews.nl/news/2 019/12/internet-savvy-elderlystill-prefer-cash-dont-trustinternet-banking/

Fadare, O. A. (2016). A survey on perceived risk and intention of adopting internet banking, Journal of Internet Banking and Commerce, 21, 1, 1-21.

Georgieva, L (2018) Digital inclusion and the elderly: The case of online banking, in Schuurman, I, Sevens, L., Yaneva, V., \& O'Flaherty, J. (Eds). Proceedings of the LREC 2018 Workshop "Improving Social Inclusion using NLP: Tools, Methods and Resources" (ISI-NLP 2), 7 May, Miyazaki, Japan, 8-12.

Gitlow, L. (2014). Technology use by older adults and barriers to using technology, Physical and Occupational Therapy in Geriatrics, 32, 3, 271-280, doi:10.3109/02703181.2014.9466 40.

Goyal, V. C. \& Dixit, U. (2008). Technology for safety and protection of elderly, in S. Bhatia, M. Cherian, \& J. R. Gupta (Eds.), Protection of life and property of senior citizens in India, All India Senior Citizens' Confederation (AISCCON), Navi Mumbai.

Hill, R., Betts, L. R., \& Gardner, S. E. (2015). Older adults' experiences and perceptions of digital technology: (Dis)empowerment, wellbeing, and inclusion, Computers in Human Behaviour, 
48 , 415-423, doi:10.1016/j.chb.2015.01.062

Hill, R., Beynon-Davies, P., \& Williams, M. D. (2008). Older people and internet engagement: Acknowledging social moderators of internet adoption, access and use, Information Technology \& People, 21, 3, 244266; retrieved July 15, 2019 from http://dx.doi.org/10.1108/095938 40810896019

Howcroft, B., Hamilton, R., \& Hewer, P. (2002). Consumer attitude and the usage and adoption of homebased banking in the United Kingdom, The International Journal of Bank Marketing, 20, 3, 111-121.

Ifezue, A. N., Ama. N. O., \& Moseki, K. K. (2016). An exploratory factor analysis of older adults' resistance to innovation adoption: A case study of University of Botswana, Journal of Management Research, 8, 4, 1943.

Jeong, B. \& Yoon, T. E. (2013). An empirical investigation on consumer acceptance of mobile banking services, Business and Management Research, 2, 1, 3140.

Jham, V. (2016). Customer satisfaction with internet banking: Exploring the mediating role of trust, Journal of Emerging Trends in Economics and Management Sciences, 7, 2, 75-87.

Jolly, V. (2016). The influence of internet banking on the efficiency and cost savings for banks' customers, International Journal of Social Sciences and

Management, 3, 3, 163-170.

Karjaluoto, H., Mattila, M., \& Pento, T. (2002). Electronic banking in Finland: Consumer beliefs and reactions to a new delivery channel, Journal of Financial Service Marketing, 6, 4, 346-361; retrieved August 9, 2019 from http://dx.doi.org/10.1057/palgrav e.fsm.4770064

Kumar, C. A. M., Reddy, Y. L. K., \& Sreenivasulu, B. (2017). The role of internet banking and society, International Journal of Science Technology and Management, 6, 1, 861-869; retrieved August 14, 2019 from http://www.ijstm.com/images/sho rt_pdf/1485605322_D563ijstm.pd $\mathrm{f}$

Laukkanen, T., Sinkkonen, S., Kivijarvi M., \& Laukkanen P. (2007). Innovation resistance among mature consumers, Journal of Consumer Marketing 24, 7, 419427; retrieved July 15, 2019 from http://dx.doi.org/10.1108/07363760710 834834

Lawhon, T., Ennis, D., \& Lawhon, D. C. (1996). Senior adults and computers in the 1990s. Educational Gerontology, 22, 2, 193-201.

Lee, M. (2009). Factors influencing the adoption of internet banking: An integration of TAM and TPB with perceived risk and perceived benefit, Electronic Commerce Research and Applications, 8, 1, 130-141.

Lee, E. J, Kwon, K. N., \& Schumann, D. W. (2005). Segmenting the 
non-adopter category in the diffusion of internet banking, The International Journal of Bank Marketing, 23, 5, 414-437.

Li, Q. \& Luximon, Y. (2018) Understanding older adults' postadoption usage behaviour and perceptions of mobile technology, International Journal of Design, 12, 3, 93-110.

Lichtenstein, S. \& Williamson, K. (2006). Understanding consumer adoption of internet banking: An interpretive study in the Australian banking context, Journal of Electronic Commerce Research, 7, 2, 50-66.

Malhotra, P. (2016). Adaptability of Internet Banking in Haryana State of India, Unpublished MBA thesis, Dublin University, India; retrieved May, 22, 2019 from http://esource.dbs.ie/bitstream/ha ndle/10788/3193/mba_pooja_201 6.pdf? sequence $=1 \&$ isAllowed $=y$

Marston, H. R., Kroll, M., Fink, D., de Rosario, H., \& Gschwind, Y. J. (2016). Technology use, adoption and behaviour in older adults: Results from the iStoppFalls project, Educational Gerontology, 42, 6, 371-387, doi: 10.1080/03601277.2015.1125178 Martins, C., Oliveira, T., \& Popovič, A. (2014). Understanding the internet banking adoption: A unified theory of acceptance and use of technology and perceived risk application, International Journal of Information Management, 34, 1, 1-13, doi: 10.1016/j.ijinfomgt.2013.06.002
Mattila, M., Karjaluoto, H., \& Pento, T. (2003). Internet Banking Adoption among mature Customers: Early majority or laggards? Journal of Services Marketing, 17, 5, 514-528.

Mbrokoh, A. S. (2015) Factors that Influence Internet Banking Adoption in Ghana, Unpublished MPhil dissertation, University of Ghana, Legon; retrieved May 14, 2019 from http://ugspace.ug.edu.gh

Mukhtar, M. (2015). Perceptions of UK based customers toward internet banking in the United Kingdom, Journal of Internet banking and Commerce, 20, 1, 1-38.

Mwesigwa, R. (2010). Consumers' attitudes, perceived risk, trust and internet banking adoption in Uganda, Unpublished master of business administration dissertation, Makerere University, Uganda; retrieved July 5, 2019 from

http://makir.mak.ac.ug/handle/10 570/2403

Näsi, M., Räsänen, P., \& Sarpila, O. (2012). ICT activity in later life: Internet use and leisure activities among senior citizens in Finland, European Journal of Ageing, 9, 2, 169-76.

Nayak, L. U. S., Priest, L., \& White, A. P. (2010). An application of the technology acceptance model to the level of internet usage by older adults, Universal Access in the Information Society, 9, 367374; retrieved June 9, 2019 from http://dx.doi.org/10.1007/s10209009-0178-8. 
Odiboh, O., Oresanya, T., \& Ekanem, T. (2016). E-commerce advertisement and usage experience: The case of Nigeria, Covenant Journal of Communication, 3, 1, 23-43.

Omotayo, F. O. (2015). Adoption and use of information and communication technologies by educated elderly people in Ibadan metropolis, Nigeria, Indian Journal of Information Sources and Services, 5, 1, 34-45.

Omotayo, F. O. \& Adebayo, A. K (2015). Factors influencing intention to adopt internet banking by postgraduate students of the university of Ibadan, Nigeria, The Journal of Internet Banking and Commerce, 20, 3, 129.

Onaolapo, A. R. \& Anene, E. C. (2016). Bank service quality, mobile connectivity and adoption of internet banking among selected university students in Oyo State, Nigeria, International Journal of Managerial Studies and Research, $4,1,38-48$.

Onyango, E. O. (2016). Investigating factors that influence the intention to adopt internet banking: a case study of USIU Africa students, Unpublished Masters in Business Administration project, Chandaria School of Business, United States International University Africa, Nairobi, Kenya; retrieved July 15, 2019 from https://pdfs.semanticscholar.org/6 431/73e486d542eabbf4553df3fa1 0a7f17eaf6f.pdf
Peek, S. T., Luijkx, K. G., Rijnaard, M. D., Nieboer, M. E., van der Voort, C. S., Aarts, S., van Hoof, Vrijhoef, H., \& Wouters, E. J. (2016). Older adults' reasons for using technology while aging in place, Gerontology, 62, 2, 226237, doi: 10.1159/000430949

Pew Research Centre (2014). Older adults and technology use: Adoption is increasing, but many seniors remain isolated from digital life; retrieved April 14, 2019 from http://www.pewinternet.org/files/ 2014/04/PIP_Seniors-and-TechUse_040314.pdf.

Piiparinen, M. (2014). Attitudes of seniors' using cash services towards online banking, Bachelor thesis, Turku University of Applied Sciences, Finland; retrieved July 3, 2019 https://www.theseus.fi/bitstream/ handle/10024/97354/ThesisMona Piiparinen\%20$\% 20$ Copy.pdf?sequence $=1 \&$ isAll owed=y.

Ramón-Jerónimo, M.A., Peral-Peral, B., \& Arenas-Gaitán, J. (2013). Elderly persons and internet use, Social Science Computer Review 2, 7, 389-403; retrieved July 4, 2019 from http://dx.doi.org/10.1177/089443 9312473421

Rock, W., Hira, T.K., \& Loibl, C. (2010). The use of the internet as a source of financial information by households in the United States: A National Survey, International Journal of Management, 27, 3, 754-778. 
Ronning, W. M. \& Solvberg, A. M. (2017). Older adults' coping with the digital everyday life, International Journal of Media, Technology and Lifelong Learning, 13, 2, 55-71.

Sayago, S., Forbes, P., \& Blat, J. (2012). Older people becoming successful ICT learners over time: Challenges and strategies through an ethnographical lens, Educational Gerontology, 39, 7, 527-544; retrieved October 9, 2019

from https://doi.org/10.1080/03601277. 2012.703583

Senali, M. G. (2017) Mobile banking adoption by senior citizens in Australia, ECU Posters; retrieved June 15, 2019 from http://ro.ecu.edu.au/ecuposters/19

Smith, A. (2014). Older adults and technology use. Washington, DC: Pew Research Centre; retrieved April 22, 2019 from http://www.pewinternet.org/2014/ 04/03/older-adults-andtechnology-use/

Sohail, M. \& Shanmugham, B. (2004). E-banking and customers' preferences in Malaysia: An empirical investigation, Information Sciences, Informatics and Computer Science: An International Journal, 150, 207217; retrieved August 5, 2019 from

http://dx.doi.org/10.1016/s00200255(02)00378-x
Tarhini, A., El-Masri, M., Ali, M., \& Serrano, A. (2016). Extending the UTAUT model to understand the customers' acceptance and use of internet banking in Lebanon: A structural equation modeling approach, Information Technology \& People, 29, 4, 830849, doi: 10.1108/ITP-02-20140034

Tarhini, A., Mgbemena, C., Trab, M. S. A., \& Masa'deh, R. (2015). User adoption of online banking in Nigeria: A qualitative study, Journal of Internet Banking and Commerce, 20, 3, 1-24.

United Nations (2015). World population ageing, Department of Economic and Social Affairs, Population Division, New York, United Nations.

Venkatesh, V., Morris, M. G., Davis, G. B., \& Davis, F. D. (2003). User acceptance of information technology: Toward a unified view, MIS Quarterly, 27, 3, 425478.

WHO (2002). Active ageing: A policy framework, A contribution of the World Health Organization to the Second United Nations World Assembly on Ageing, Madrid, Spain, April 2002.

Yousafzai, S. \& Yani-de-Soriano, M. (2012). Understanding customer-specific factors underpinning internet banking adoption, International Journal of Bank Marketing, 30, 1, 60-81, doi:10.1108/02652321211195703 